\title{
An Investigation on Attitude Towards Learning Mathematics Among Higher Secondary School Students
}

\author{
Dr. Moyuri Sarma ${ }^{1}$, Ms. Minakshi Rabha ${ }^{2}$ \\ 1Assistant Professor, Department of Education, Gauhati University, Assam \\ ${ }^{2}$ Research Scholar, Department of Education, Gauhati University, Assam \\ ${ }^{1}$ moyurisarma89@gmail.com, ${ }^{2}$ minakshirabha2@gmail.com
}

\begin{abstract}
While assessing mathematics performance, attitude towards mathematics and Mathematics learning are frequently cited as factors contributing to success. The present study has been conducted to investigate students' attitude towards learning mathematics in the higher secondary schools of Assam, India. It is sought to understand the influence of Gender and School Environment (Government and Private) in the study of the subject Mathematics. ATMS (Attitude Towards Mathematics Scale), developed by Dr. S. C. Gakhar, and Dr. Rajni was used to find out the attitude of students towards learning mathematics and their achievement in mathematics both in terms of gender as well as school management pattern. Out of a population of 340 students studying at the higher secondary (10+1) level in the Balijana Block of Goalpara District, a sample of 102 students (56 boys and 46 girls) were selected through Stratified Random sampling technique. One Provincialized, one Government and two Private schools were selected based on purposive sampling technique. The achievement of the students in Mathematics at higher secondary level depends on the gender of the students. The study revealed that achievement level of the male students in Mathematics at higher secondary level is more than that of their female counterparts. The achievement of the students in Mathematics at higher secondary level depends on the school environment. The achievement level of the students in private schools is better than the Government schools. The male students show more positive attitude towards learning Mathematics than the female students. Among the eight components, in few components students of Government schools show more positive attitude than Private schools. Whereas, in some components students of Private schools show more positive attitude than students of Government schools. Therefore, attitudes towards mathematics can be developed through encouraging students and motivating them for learning through constructivism and innovations. Teachers, school environment and home environment should be conducive and shouldn't hamper students' mathematical performance throughout their schooling
\end{abstract}

Keywords

Attitude, Mathematics, Gender, School Environment, Higher Secondary Schools

Article Received: 10 August 2020, Revised: 25 October 2020, Accepted: 18 November 2020

\section{Introduction}

Mathematics is an important school subject. Mathematics makes our lives orderly and prevents chaos. Certain qualities that are nurtured by Mathematics are power of reasoning, creativity, abstract or spatial thinking, critical thinking, problem- solving ability and even effective communication skills. Considering the importance of Mathematics, all great educationists like Herbert, Pestalozzi etc. has accepted Mathematics as a symbol of human development. Accepting Mathematics as a best means of intellectual and cultural developments, these educationists placed Mathematics on the top in the curriculum.

While assessing mathematics performance and potential of students, Attitude towards mathematics and Mathematics learning are frequently cited as factors contributing to success. Several studies have shown that positive Attitudes are conductive to good performance. However, an individual's Attitude towards Mathematics can be influenced by many factors. Among them, two factors are most important. Firstly, individual's gender and secondly, socio-economic condition of the students. In general, attitudes, beliefs and emotions are the major descriptors of the affective domain in Mathematics education, whereas knowledge and thinking are considered descriptors of the process of human mind. Mathematics educators have traditionally taken the relationship between

Attitude toward Mathematics and achievement in Mathematics as the major concern. ${ }^{1}$

The word "Mathematics" has been used in two distinct difference senses, i.e., one as a method used to solve the problems of quantity, space, order etc. and the second as a set of law or generalizations of truth that are discovered. ${ }^{2}$

The term Mathematics may be defined in a number of ways. In an exact science meaning of the word Mathematics is "The science in which calculations are prime".

It is highlighted in National policy on education (1968) as follows:

"Mathematics should be visualized as the vehicle to train a child to think, reason, analyze and articulate logically. Apart from being a specific subject it should be treated as a concomitant to any subject involving analysis and meaning."

According to Bertrand Russell, "Mathematics may be defined as the subject in which we never know what are thinking about, nor whether what are saying is true."3

According to Galileo, "Mathematics is the language in which GOD has written the universe."

In this context Kothari Commission (1964-66) suggested that "Science and Mathematics should be taught on a 
compulsory basis to all pupils as a part of general education during first ten years of schooling."

\subsection{Value Of Teaching The Subject Mathematics}

Values are regarded as desirable, important and are held in high esteem by people who live in a particular society. Thus, values give meaning and strength to the character of a person. Therefore, values reflect one's personal attitude, judgements, decisions, choices, behavior, relationship, dreams and vision. Mathematics helps in attaining and developing various values among the children. Mathematics teaching must focus on Intellectual, Disciplinary, Moral, Social, Value related scientific attitude and Vocational values. ${ }^{5}$

\subsection{Status Of The Subject}

Curriculum includes all those activities, experiences and environment which the child receives during one's educational career under the guidance of educational authorities. In education, the importance and the place of a subject on the fact that "to what extent the subject is helpful in achieving the aims of education." If any subject is more useful for achieving educational objectives then its importance increases accordingly. Being so important in school, Kothari Commission has explained about placing Mathematics as a compulsory subject up to higher secondary or tenth standard.

\subsection{Attitude}

Although there is no standard definition of the term Attitude, in general it refers to a learned predisposition or tendency on the part of an individual to respond positively or

negatively to some object, situation, concept or another person. In assessing mathematics

performance and potential of students, Attitude towards mathematics and Mathematics learning are frequently cited as factors contributing to success. Several studies have shown that positive Attitudes are conductive to good performance.

The achievement of students in different subjects depends on the level of attitude of the students towards the subjects they were studying. Students with more favourable attitude towards schooling were found to be higher achiever in general. The foundation of success, of our chosen field, is attitude. Just like a great building stands on a strong foundation. ${ }^{6}$ The same may be with Attitude towards Mathematics and performance in mathematics.

\section{Review of related literature:}

The various studies reviewed are broadly classified under the following heads:

Baruah, (1989-1990) conducted a study on "The Attitude of the students towards Mathematics in Dibrugarh town" and found that there was significant difference between boys and girls in terms of their mean attitude scores.

Baskaran (1991) in the study on "Achievement- motivation, attitude towards problem solving and achievement in mathematics of the students in Devakottai Educational District" revealed that there was a positive relationship between the attitude towards problem- solving and achievement in Mathematics. There was no difference in the attitude of boys and girls towards Mathematics.

Basavayya (1995) has conducted a study on the students' perceptions of Mathematics and found that there was a positive correlation between perception (attitude) and achievement in Mathematics.

Srinivasan (1999), in his study has found that the attitude of the students towards study of Mathematics had the highest correlation with mathematical achievement. From the above study findings, it can be implied that there is a need to develop love and a positive favourable attitude towards Mathematics among students at different levels.

Hombo and Mazzeo, (2000) has shown that parents' educational level not only impact student attitude towards learning but also impact their mathematical achievement scores. For instance, students whose parents had less than high school education obtained lower grades in Mathematics than those whose parents had higher levels of education.

Zakaria, (2009) conducted a study on "Attitudes and Problem- Solving Skills in Algebra among Malaysian students and reported that there is no significant mean difference on the students' attitude towards algebraic problem- solving when evaluated with respect to gender.

4. Mahanta and Islam (2012) in the study on "Attitude of Secondary students towards Mathematics and its relationship to achievement in Mathematics" concluded that boys show more positive attitude towards Mathematics than girls. Also attitude of students and achievement are positively correlated.

Krinzinger, (2012) on the study on Attitude towards Mathematics found the effects of individual, Motivational and Social Support factors in the findings concerning the relationship between achievement and attitude towards Mathematics. The study found that good achievers develop more positive attitude than lower achievers. Achievement is usually related to self- belief in competence and it can be related to attitude towards Mathematics which suggests that when students succeed at a Mathematics task, it increases their sense of competence and this promote more positive attitude.

Mazana, (2018) on the study on Investigating students' Attitude towards Learning Mathematics found that students' learning of and performance in mathematics is affected by a number of factors, including students' attitude towards the subject, teachers instructional process and school environment.

\section{Significance Of The Study}

The study on attitude of students towards learning Mathematics and its relationship with achievement may help us to find out the learning gaps as well as the personal factors associated with students' achievement. From this study it can be able to understand the role played the educational institution for positive attitude formation among the students towards learning Mathematics. This will help the teaching fraternity to understand the phobias associated with the subject Mathematics and take remedial measures to overcome the same. 


\section{Statement Of The Problem}

The present problem is titled as:

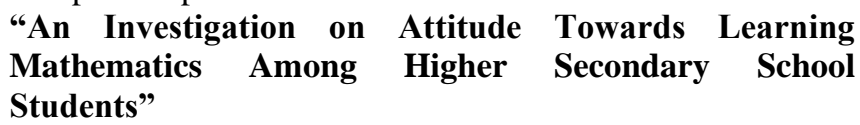

\section{Objectives Of The Study}

1. To enquire the level of achievement of Higher Secondary students in Mathematics.

2. To compare the attitude towards Mathematics among male and female students of higher secondary schools.

3. To compare the attitude towards Mathematics of the students of the Government and Private higher secondary schools.

\section{Research Questions}

The researcher has raised the following research questions in this study:

1. Whether the achievement in Mathematics is dependent on the attitude towards learning of Mathematics?

2. Do male and female students of higher secondary level have different attitude towards Mathematics?

3. Do the students of Government and Private higher secondary schools have different attitude towards Mathematics?

\section{Delimitations of the study:}

1. Achievement will only be studied in relation to marks secured in Mathematics in the Higher Secondary $1^{\text {st }}$ Year examination.

2. The study is delimited to the Balijana Block of Goalpara District.

3. The data is collected only from the Higher Secondary first year students.

\section{Methodology Of The Study}

Research Method: The present study is based on Descriptive Survey method.

Sources of Data: The data has been collected from Primary sources like attitude scale, personal interview, observation and secondary sources namely, school register and records etc

Population and Sample: The population of the study has been defined as the students studying at higher secondary $(10+1)$ level in the Balijana Block of Goalpara District. Purposive sampling technique has been used for selecting the schools. One Provincialized, one Government and two Private schools were selected for the study. Total population of the study is 340, out of which 102 (56 male and 46 female) students studying in higher secondary first year are selected through Stratified Random sampling technique.

Research Tools:

Attitude Scale: ATMS (Attitude Towards Mathematics Scale), developed by Dr. S. C. Gakhar, Department of Education, Punjab University, Chandigarh (Punjab) and Dr.
Rajni, Department of Education, Punjab University, Chandigarh (Punjab) in 2012.

Norms for interpretation of Z- Score for Levels of Attitude towards Mathematics is given below:

Table 1: Norms for interpretation of Z- Score Norms for Levels of Attitude towards Mathematics

\begin{tabular}{|c|c|c|c|}
\hline $\begin{array}{l}\text { Sl. } \\
\text { No. }\end{array}$ & $\begin{array}{l}\text { Range of } \\
\text { z- scores }\end{array}$ & Grade & $\begin{array}{l}\text { Levels of Attitude } \\
\text { Towards Mathematics }\end{array}$ \\
\hline 1 & $\begin{array}{l}+2.01 \text { and } \\
\text { above }\end{array}$ & A & Extremely favourable \\
\hline 2 & $\begin{array}{l}+1.26 \text { to } \\
+2.00\end{array}$ & B & High favourable \\
\hline 3 & $\begin{array}{l}+0.51 \quad \text { to } \\
+1.25\end{array}$ & $\mathrm{C}$ & $\begin{array}{l}\text { Above } \\
\text { favourable }\end{array}$ \\
\hline 4 & $\begin{array}{ll}-0.50 & \text { to } \\
+0.50 & \\
\end{array}$ & $\mathrm{D}$ & $\begin{array}{l}\text { Average/Moderate } \\
\text { favourable }\end{array}$ \\
\hline 5 & $\begin{array}{l}-0.51 \text { to }- \\
1.25\end{array}$ & $\mathrm{E}$ & $\begin{array}{l}\text { Below } \\
\text { favourable }\end{array}$ \\
\hline 6 & $\begin{array}{l}-1.26 \text { to }- \\
2.00\end{array}$ & $\mathrm{~F}$ & Highly unfavourable \\
\hline 7 & $\begin{array}{l}-2.01 \text { and } \\
\text { below }\end{array}$ & G & Extremely unfavourable \\
\hline
\end{tabular}

Personal Interview: Personal interview has been conducted to enquire the phobia for Mathematics subject among the students.

\section{Variables Of The Study}

While studying attitude of students towards learning Mathematics following variables have been taken into account:

1. Achievement of the students in mathematics

2. Gender of the students (Male/ Female).

3. Type of management of the schools (Government/ Private).

In the present study, while establishing the relationship between attitude of student towards Mathematics and their achievement in mathematics, attitude has been considered as independent variable and achievement as dependent variable.

\section{Analysis of data:}

The analysis of the study is done objective wise:

\section{Objective 1: Achievement Of The Students At Higher Secondary Level In Mathematics}

Mathematics is a core subject in secondary schools. In various Researches it has been shown that Mathematics achievement in students is influenced by psychological factors such as Mathematics anxiety. According to Tobias (1995), "Mathematics anxiety is a feeling of tension and it appears when someone is engaged in the manipulation of figures to solve mathematical problems in both academic and daily- life situations."

The research of Tobias revealed that there are many female students at the secondary and university level who change their subjects because of the feeling of fear for Mathematics. This has happened not because these women have lower intellectual capacity but because of the phobia for the 
subject. Mathematics anxiety was defined as the level of discomfort that occurs among the students in response to situations involving mathematical tasks, which is seen as a threat to their self- ability.

\section{Objective 2: Gender-Wise Achievement Of The Students Of Higher Secondary Level In Mathematics}

According to some researchers' female students believed that boys are blessed with the advantage of mastering Mathematics, while the boys feel they are better able to perform in Mathematics when compared with their female counterparts. Such beliefs negatively affect the ability of female students and their initial assumptions about Mathematics achievement can have a long-term impact on their achievement in Mathematics. Line Graph showing gender wise achievement of marks obtained in HS $1^{\text {st }}$ Year in mathematics.

Figure 1: Line diagram showing gender-wise achievement of higher secondary students in Mathematics

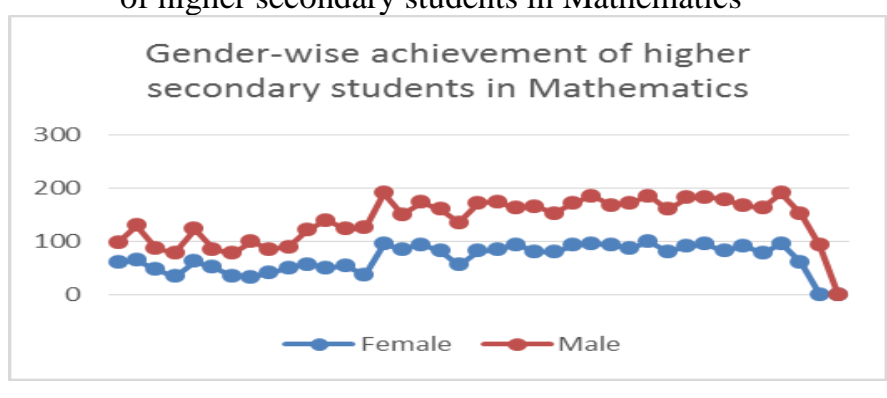

\section{Interpretation:}

From the above figure we can conclude that the level of achievement of male students is higher than the female students in Mathematics at first year higher secondary class. The average level of achievement of male students in Mathematics is 73.947 and the average of level of achievement of female students in Mathematics is 71.756.

Objective 3: Achievement Of The Students In Mathematics In The Government And Private Schools

The line graph depicting the marks obtained in HS $1^{\text {st }}$ Year Examination by students Government and Private institutions.

Figure 2: Line Graph showing achievement of the students at higher secondary level in Government and Private institutions

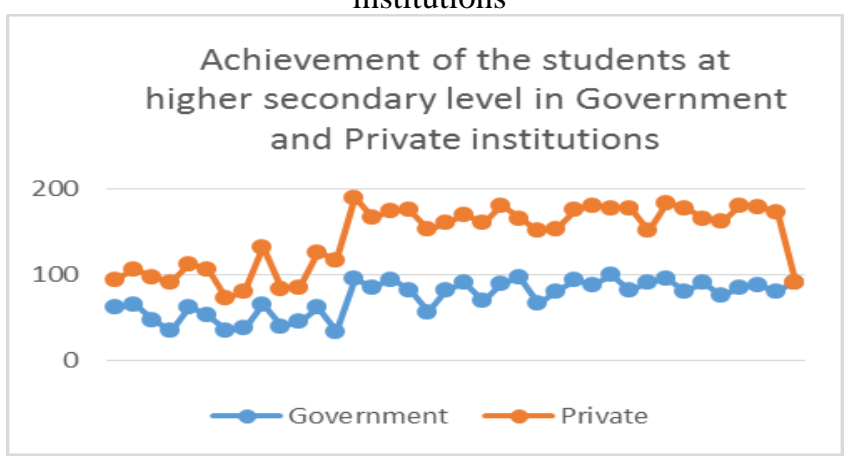

Interpretation:
From the above figure we can conclude that the level of achievement of the students of Government schools is lower than the students of Private schools in Mathematics in the first year higher secondary class. The average level of achievement of students of Government schools is 72.5 whereas, the average level of achievement of students in Private school is 73.24 .

\section{Gender-Wise Analysis Of Students For Their Attitude Towards Mathematics}

Table 2: Gender-wise mean component scores of attitudes

\begin{tabular}{|l|l|l|}
\hline Name of the Component & Male & Female \\
\hline Wider Applicability & 189.89 & 187.27 \\
\hline Development of Skills & 74.12 & 81.41 \\
\hline Reasoning & 49.72 & 49.48 \\
\hline Objectivity & 91.25 & 88.06 \\
\hline Intellectual Development & 108.20 & 102.47 \\
\hline $\begin{array}{l}\text { Non- Intellectual } \\
\text { Development }\end{array}$ & 68.89 & 72.67 \\
\hline Individual Outlook & 103.16 & 100.21 \\
\hline Universal Outlook & 55.89 & 52.74 \\
\hline
\end{tabular}

\section{Interpretation:}

Attitude of the students towards Mathematics depends on gender. The male students show more positive attitude towards Mathematics than the female shtudents.

Figure 3: Multiple Bar diagram showing the gender-wise attitudes of the students towards Mathematics

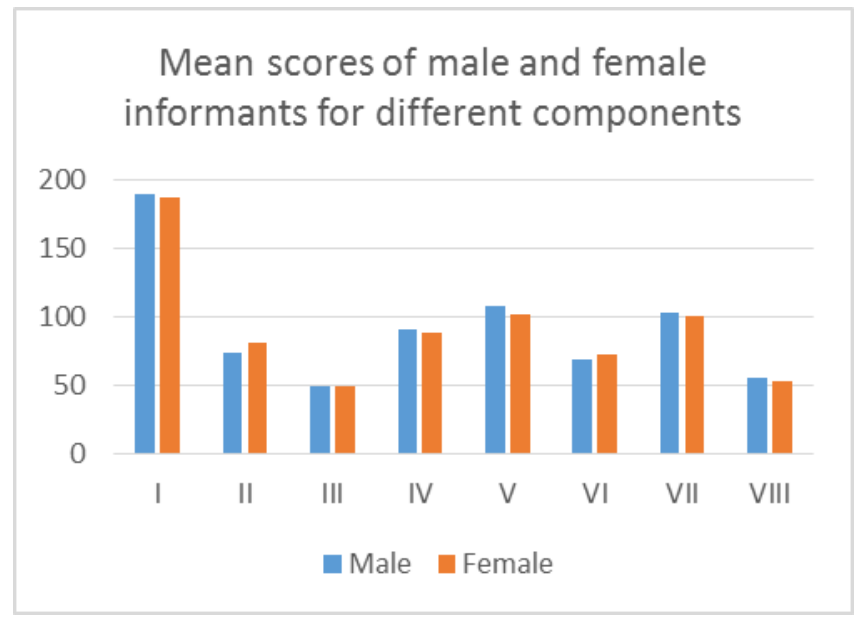

\section{Interpretation:}

After calculating all the eight components for male and female students separately, it can be observed that Wider Applicability is maximum for both the male and female students, which is $25.56 \%$ and Reasoning is minimum for both the male and female students, which is $6.72 \%$. The percentage of other components are Development of skills is $10.54 \%$, Objectivity is $12.15 \%$, Intellectual Development is $14.28 \%$, Non-intellectual Development is $9.59 \%$, Individual outlook is $13.78 \%$ and Universal Outlook is $7.36 \%$. The difference of attitude between male and female students is maximum in case of Development of Skills and minimum in case of Reasoning towards Mathematics. However, the 
difference among male and female respondents in respect to the components are found quite neglegible.

\section{Comparision Between The Attitude Of The Students Of Government And Private Higher Secondary Schools}

Table 3: Mean component scores of attitudes of the students of government and private higher secondary schools

\begin{tabular}{|l|l|l|}
\hline $\begin{array}{l}\text { Name of the } \\
\text { Component }\end{array}$ & $\begin{array}{l}\text { Student of } \\
\text { Government } \\
\text { school }\end{array}$ & $\begin{array}{l}\text { Student of } \\
\text { Private } \\
\text { school }\end{array}$ \\
\hline $\begin{array}{l}\text { Wider } \\
\text { Applicability }\end{array}$ & 187.11 & 190.05 \\
\hline $\begin{array}{l}\text { Development of } \\
\text { Skills }\end{array}$ & 79.65 & 67.27 \\
\hline Reasoning & 48.37 & 49.72 \\
\hline Objectivity & 88 & 91.31 \\
\hline $\begin{array}{l}\text { Intellectual } \\
\text { Development }\end{array}$ & 103.85 & 106.79 \\
\hline $\begin{array}{l}\text { Non- Intellectual } \\
\text { Development }\end{array}$ & 75.35 & 76.06 \\
\hline $\begin{array}{l}\text { Individual } \\
\text { Outlook }\end{array}$ & 91.14 & 92.72 \\
\hline $\begin{array}{l}\text { Universal } \\
\text { Outlook }\end{array}$ & 53.95 & 54.64 \\
\hline
\end{tabular}

\section{Interpretation:}

The students of Private schools display more positive attitude towards Mathematics than the students of Government schools.

Figure 4: Multiple Bar diagram showing the attitudes of the students of higher secondary level towards Mathematics in Government and Private schools

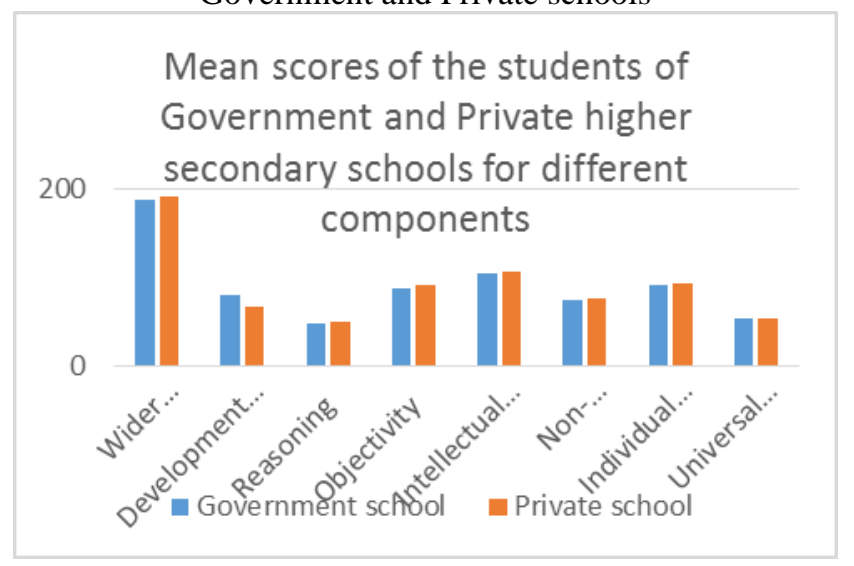

\section{Interpretation:}

When scores of all the eight components are calculated for students of Government and Private school, then it can be observed that Wider Applicability is maximum for both the Government and Private school students, which is $25.9 \%$ and Reasoning is minimum for both the Government and
Private school students, which is $6.73 \%$. The percentage of other components is Development of skills is $10.09 \%$, Objectivity is $12.31 \%$, Intellectual Development is $14.47 \%$, Non-intellectual Development is $10.4 \%$, Individual outlook is $12.63 \%$ and Universal Outlook is $7.46 \%$. The difference of attitude between students of Government and Private schools is maximum in case of Development of Skills and minimum in case of Universal Outlook towards Mathematics. The difference between students of Government and Private schools in respect to the components are found quite neglegible.

\section{Analysis Of The Data With Respect To The Table Of Z- Score Norms For Levels Of Attitude Towards Mathematics}

With the help of the Table 2, we can say that most of the male students show high favourable $(+1.26$ to +2.00$)$ levels of Attitude Towards Mathematics and most of the female students show average/ moderate favourable $(-0.50$ to +0.50$)$ levels of Attitude towards Mathematics in higher secondary first year class.

With the help of the Table 3, we can say that most of the Private school students show high favourable $(+1.26$ to +2.00 ) levels of Attitude Towards Mathematics and most of the Government school students show above average favourable $(+0.51$ to +1.25$)$ levels of Attitude towards Mathematics in higher secondary first year class.

\section{Findings}

Some important facts emerged during the course of study:

1. The achievement of the students in Mathematics at higher secondary level depends on the gender of the students. The achievement level of the male students in Mathematics at higher secondary class is more than that of their female counterparts.

2. The achievement of the students in Mathematics at higher secondary level depends on the school environment. The achievement level of the students in private schools is better than the Government schools.

3. From the study we can say that the attitude towards Mathematics depends on gender. The male students show more positive attitude towards learning Mathematics than the female students.

4. Among the eight components both the male and female students show highest positive attitude in Wider Applicability and they show lowest positive attitude in Reasoning.

5. Among the eight components in some components male students show more positive attitude than female students and in some components female students show more positive attitude than male students towards Mathematics.

6. Among the eight components both the Government school and Private school students show highest positive attitude in Wider Applicability and they show lowest positive attitude in Reasoning.

8. Among the eight components in some components students of Government school show more positive attitude than Private schools. Whereas, in some components students of Private schools show more positive attitude than students of Government schools. 


\section{Suggestions:}

In order to improve the achievement of students in mathematics the following suggestions may be put forwarded-

1. Teacher should use innovative ideas in teaching the subject Mathematics and child centered methods and techniques must be used so that students can understand easily and clearly.

2. The teachers should always try to provide concrete ideas so that the abstract problems, formulas, theorems etc. of Mathematics can be solved by the students independently.

3. Parents and gurdians of the students should give due attention to develop a positive attitude of the students towards Mathematics.

4. The members of the regulatory bodies of the schools should give importance to develop a positive attitude of the students towards Mathematics such that they can provide more facilities to their students.

\section{Conclusions}

On the basis of the findings may be concluded that the achievement of the students in Mathematics at higher secondary level depends on the gender of the students. Because male students have more positive attitude towards mathematics than the female students. Achievement level of students in mathematics in Government schools is less than private schools. From the study we can say that the attitude towards Mathematics depends on the gender of the students and type of the school. Therefore, attitudes towards mathematics can be developed through encouraging students and motivating them for learning through constructivism and innovations. Teachers, school environment and home environment should be conducive and shouldn't hamper students' mathematical performance throughout their schooling.

\section{References}

[1] Sahu, B. K. (2004), "Teaching of Mathematics", Kalyani Publishers, New Delhi, ISBN: 81-272-1435-3.

[2] Sahu, B. K. (2004), "Teaching of Mathematics", Kalyani Publishers, New Delhi, ISBN: 81-272-1435-3.

[3] Agarkar, S.C. (1997), "Programme to Improve Teaching of Science and Mathematics in Rural Secondary Schools", Jour. Of Indian Education,XXIII (2) Pp. 60-68.

[4] Doshi, P. C. (1989), "A Study of Achievement And Cognitive Preference Styles in Mathematics of Class X Students", University of Rajasthan.
[5] Mahanta, N.N. , Das, D., Borah, H. N., Adhikary, A. (2014), " Contemporary Concerns and Issues in India", Mani Manik Prakash.

[6] Manhas, S. and Sharma, M. (2008), “ Attitude of Students Towards Subjects", Praachi Journal of Psycho-Cultural Dimensions,Pp. 33-37.

[7] Ma, X. and Kishor, N. (2004), “ Assessing The Relationship Between Attitude Towards Mathematics And Achievement in Mathematics", American Journal of Education, Pp. 256-280. 